\title{
ШВЕДСЬКИЙ ІНСТИТУТ: СКАНДИНАВСЬКИЙ ДОСВІД НАЛАГОДЖЕННЯ МІЖНАРОДНИХ ЗВ'ЯЗКІВ ТА СТВОРЕННЯ МОЖЛИВОСТЕЙ ДЛЯ ВЗАСМОДІЇ ШВЕДІВ ЗІ СВІТОМ
}

\begin{abstract}
Анотація. У даній статті досліджено особливості функціонування Шведського інституту, що відіграе важливу роль у зміцненні міжнародної суб'єктності країни засобами культурної дипломатії і не тільки. Зокрема, висвітлено передумови та процес становлення даної інституції, що успішно працюе протягом останніх 76-и років. Проаналізовано структуру, функції, завдання та місію Шведського інституту у сфері громадської дипломатії. У статті розглянуто установчі документи, засоби фінансування, стратегію розвитку та основні напрямки програмної діяльності Інституту. Також охарактеризовано зміст та інструменти, зокрема наповнення у соціальних мережах (Facebook, Twitter та Instagram), запуск інформаційних порталів таких як: Sweden.se, Sharing Sweden, Image Bank Sweden тощо, а також організація програм з академічної мобільності, суспільно-просвітницьких заходів, професійного обміну, фрінансування приватних культурних і комерційних проєктів, пов'язаних зі Швецією за кордоном. Розглянуто географію поширення та роль зазначеної організації у формуванні міжнародного іміджу та репрезентації Королівства Швеції через потенціал культури та економіки у світі.
\end{abstract}

Ключові слова: громадська дипломатія, Шведський інститут, міжнародна співпраця, програми обміну, зовнішня комунікація, адміністрування міжнародних проєктів.

Klymchuk Iryna
Lviv Polytechnic National University

SWEDISH INSTITUTE: THE SCANDINAVIAN EXPERIENCE OF ESTABLISHING INTERNATIONAL RELATIONS AND CREATING OPPORTUNITIES FOR SWEDISH INTERACTION WITH THE WORLD

Summary. Swedish public diplomacy has been actively developing for the last 76 years since the establishment of the Swedish Institute (1945), a specialized institution. This initiative was supported by the Swedish academic community and the Ministry of Foreign Affairs. In 1945, the Charter of the Swedish Institute was developed, which states (Chapter 1) that the key goals of the organization are the development of cultural, social and economic relations with foreign countries by coordinating educational activities abroad, as well as, by creating new directions for cultural exchange. It is investigated that within seventy-six years this Institute has managed to form effective tools and mechanisms for international cooperation and has become one of the central bodies in the system of public diplomacy of the country. After analyzing the structure of the Swedish Institute, it should be noted that from the very beginning of its activities, the organization can exercise a wide range of powers in various fields to ensure the effectiveness of national public diplomacy with the widest arsenal of tools. With the development of the Swedish Institute, the scope of these powers expanded: if at the initial stage the organization was engaged only in the administration of cultural projects abroad and publishing specialized literature on Swedish society, then later the Institute began to carry out its own academic, cultural and economic projects. It was found that the main functions of the Institute include: developing a strategy for image policy and public diplomacy in general, coordination of academic mobility, dissemination of information about Sweden, cooperation in culture and business, learning Swedish, managing the department of Swedish Institute in Paris. We came to the conclusions that the activities of the Swedish Institute are extremely wide, in particular, all projects can be grouped into several main areas: expert support of private and public entities interested in promoting the Swedish image and experience abroad; academic mobility projects, social and educational activities, professional exchange, funding of private cultural and commercial projects related to Sweden abroad. Effective tools for public diplomacy of the Swedish Institute include information content on social networks (Facebook, Twitter та Instagram); launch of information portals such as: Sweden.se, Sharing Sweden, Image Bank Sweden, etc. It is important to emphasize the functional dualism of this organization, which is a combination of cooperation in both cultural and economic spheres. After all, since the founding of the Swedish Institute, it was decided that the country will be represented not only by officials, cultural figures, scientists and artists, but also entrepreneurs. In the profile organizations of other countries such a combination is not used, which significantly distinguishes the Institute from other relevant organizations in the world.

Keywords: public diplomacy, Swedish Institute, international cooperation, exchange programs, external communication, administration of international projects.

$\Pi$ остановка проблеми. Громадська дипломатія Швеції як відносно новий різновид дипломатії поступово розвивається ось уже протягом сімдесяти шести років. Вона зосереджена на позбавленні негативних наслідків політики нейтралітету в період Другої світової війни, а протягом 50-80-х рр. XX ст. - на створенні більш помітного та привабливого образу країни на міжнародній арені за допомогою просування її національних особливостей та інтересів. Громадська дипломатія Швеції почала суттево видозмінюватися протягом 1990-х-2000-х рр., змістивши свій акцент виключно на особливостях культурного і суспільного життя. 
Аналіз останніх досліджень і публікацій. Здійснення комплексного дослідження у рамках визначеної теми вимагало опрацювання різноманітних публікацій, аналітичних матеріалів вітчизняних, російських та закордонних авторів, що стосуються: процесу становлення та розвитку громадської дипломатії і національного брендингу Швеції; інструментів реалізації громадської дипломатії країни, а також стратегії її розвитку (Белінська Т., Вовчук Л., Боголюбова Н.М., Николаева Ю.В., Зольнова М.Г., Clerc, L., Glover, N., Jordan P., Glover N.).

Формулювання завдання дослідження. Дослідити особливості фонкціонування Шведського інституту як важливого суб'екта громадської дипломатії. Зокрема, висвітлити передумови та процес становлення даної інституції. Проаналізовати структуру, функції та основні напрямки діяльності Шведського інституту. Також розкрити інструменти та вплив зазначеної організації у сфері громадської дипломатії Швеції.

Виклад основного матеріалу. Шведська громадська дипломатія активно розвиваеться протягом останніх 76-и років 3 моменту створення Шведського інституту (1945р.) - профільної установи. Дана ініціатива була підтримана академічною спільнотою Швеції та Міністерством закордонних справ. Спочатку було створено дві організації, що відповідали за зовнішню політику у сфері культури і освіти: «Рада Просвітництва» i «Культурна Рада», які згодом були об'еднані у Шведський інститут культурного обміну з іноземцями [3]. Однією з причин створення даної організації стало бажання шведської політичної еліти покращити імідж своєї країни у світі, який постраждав від політики нейтралітету під час Другої світової війни, яка відверто носила пронімецький характер. Зокрема, протягом всіеї війни Швеція постачала Вермахту залізну руду, а в 1941 році шведські залізниці використовувалися для транзиту німецьких дивізій, одиниць зброї та боєприпасів з Норвегії до Фінляндії.

У 1945 р. було напрацьовано Статут Шведського інституту (який до сьогодні не зазнав значних змін), де зазначається (Розділ 1), що ключовими цілями організації є розвиток культурних, соціальних і економічних відносин з іноземними державами шляхом координації просвітницької діяльності за кордоном, а також, шляхом створення нових напрямків для культурного обміну [5].

У 40-х рр. Шведський інститут здебільшого спеціалізувався на культурних обмінах. Тобто, дана асоціація відповідала за покращення репутації країни у світі, консультуючись 3 діячами культури, науки, представниками бізнесу та громадськими активістами. В цей період зростае зацікавлення до Швеції за кордоном. Зокрема, виходять перші друковані видання: «Довідник про Швецію» та «Факти про Швецію». Під егідою інституту до Швеції наносять візити соціальні працівники, члени профрспілок, лідери громадських рухів та дослідники з різних куточків світу. Також відбуваються академічні обміни з науковцями з США, Великої Британії та Німеччини. Шведські твори мистецтва, ремесла та архітектура експонуються на виставках в Парижі і Мілані. Також, найбільшого резонансу набула у світі виставка «Швеція сьогодні». У сфері кінематографу був відзначений нагородою «Оскар» фрільм Арне Саксдорфа «Люди в місті» (1949р.), знятий на замовлення Шведського інституту [8].

На перших порах громадська дипломатія Швеції не мала чіткої стратегії розвитку, тому робота представництв, інститутів і окремих політичних діячів залежала від поточної кон'юнктури. З 1945 по 1970-і рр. Шведський інститут був двигуном та представником своеї держави за кордоном. Головними об’єктами громадської дипломатії Швеції стали країни Європи і США, де Шведський інститут мав намір викликати защікавленість своєю країною, шляхом вивчення її способу життя за допомогою згадок про державу у західній пресі (переважно у фокус потрапляли німецькі, французькі, британські та американські часописи). Так, з 1968 р. МЗС Швеції починае публікувати щорічні звіти про спосіб життя Швеції в іноземних 3МI - «Sverige i utländsk press» («Швеція в зарубіжній пресі»). Їx мета полягала в аналізі тенденцій з формування думок про країну за кордоном [4].

Дана стратегія була обумовлена стурбованістю шведської політичної еліти з приводу слабкої іміджевої політики країни, яку здійснював Шведський інститут в рамках просвітницької діяльності, що потерпала від історичної пам'яті та упереджень сформованих в роки Другої світової війни, а також в умовах "холодної війни». В результаті першого звіту Шведського інституту було зроблено висновок про те, що в різних регіонах світу сприйняття Швеції носило контрастний характер, проте було створено загальне уявлення про країну. В зв'язку з тим, що можливості офіційних осіб займатися формуванням нового національного бренду і його просуванням були обмежені через недостатній розвиток інформаційних технологій, головним завданням стало відстеження неправдивої інформації і міфів, що впливають на формування іміджу держави у світі.

Протягом 50-х pp. зростае інтерес до поїздок у Швецію задля запозичення досвіду у сфрері охорони здоров'я, освіти, новітніх технологій, споживчої кооперації, містобудування, які організовуе та координуе Шведський інститут. Водночас компанія Sweden Information видае та поширюе інформаційні бюлетні з різних галузей декількома іноземними мовами. Розпочинаеться розквіт шведського дизайну. Так, асоціація Svensk Form спільно з Шведським інститутом проводять виставки і тури по світу.

У 60-х рр. Шведський інститут розширюе свою діяльність у декількох сферах. Зокрема, забезпечуе присутність шведських митців у театральних та музичних фестивалях за кордоном. Шведське мистецтво виробів зі скла привертає увагу у світі, а також зростае інтерес до художніх фільмів знятих за мотивами творів Інгмара Бергмана. У 1966 році засновуеться Рада з інформування, що координуе діяльність різних учасників та груп, зосереджених на профрілювання Швеції за кордоном.

У 1970 р. Шведський інститут культурного обміну з іноземцями був перейменований на Шведський інститут. В цей період були добре налагодженні зв'язки з країнами Західної Європи і США, а також до певної міри зі Східною Європою. У сфері науки і освіти Шведський інститут 
розробляе ряд програм гостьових стипендій, на які можуть подаватися усі бажаючі з різних куточків світу. Протягом 1973-1974 рр. було організовано понад 1300 програм для відвідувачів до Швеції. Також у 1971 р. був відкритий Шведський культурний дім в Парижі, котрий займався організацією виставок, конференцій, концертів, кінопоказів, курсів з вивчення шведської мови [2].

У 80-і рр. однією 3 найбільших інвестицій десятиліття виявилася відома скандинавська групова виставка "Scandinavia Today» в США, присвячена Північному сяйву та скандинавському мистецтву. Також великий успіх мав фестиваль Meet India організований за участю Шведського інституту по всій країні. Шведська мова була включена у навчальну програму восьми вищих навчальних закладів в Естонії, Латвії і Литві. Також Шведський інститут організовуе більше 70-и семінарів з соціальних питань у США.

Упродовж 1990-х рр. Шведський інститут активно займався організацією та проведенням семінарів 3 передачі шведського досвіду у сфрері управління, демократії і права людини. Також одним 3 найбільших та найуспішніших культурних заходів під егідою Шведського інституту став проєкт під назвою «Сонце і Полярна зірка» у Великому палаці в Парижі [1].

Станом на сьогодні Інститут успішно накопичуе знання та досвід у сорері громадської дипломатії і національного брендингу, щоб розвивати інструменти та механізми співпраці 3 іншими країнами. 3 розвитком інформаційно-комунікаційних технологій Шведський інститут намагаеться бути присутнім на різних цифрових платформах та майданчиках, зокрема у соціальних мережах на Facebook, Twitter та Instagram. Запуск інформаційного порталу Sweden.se у 2004 p. так званих «інформаційних воріт до Швеції, ще дужче посприяв розповсюдженню інформації про країну. Сайт повністю адмініструється Шведським інститутом, де розміщуеться індормація англійською, китайською, арабською і російською мовами, надаючи уявлення про різні аспекти життя сучасної Швеції. Даний веб-сайт слугуе інструментом громадської та іміджевої дипломатії, що просуває образ Швеції як країни з унікальною природою, самобутньою культурою, розвинутою економікою, високим рівнем прав та свобод. Також, відома веб-платформа Sharing Sweden 3 легкодоступними матеріалами про Швецію слугує інформаційним ресурсом для іноземної цільової аудиторії, що цікавиться Швецією та шведами. Так званий офріційний банк зображень про Швецію - Image Bank Sweden, що також адмініструеться Інститутом, містить тисячі зображень, які демонструють повсякденне життя шведів та відображають такі теми як шведські інновації, сталість, культура і творчість. Важливо зазначити, що в період пандемії Шведському інституту довелося переглянути свою політику та інструменти зовнішньої комунікації. Серед іншого, робота з аналізом іміджевої політики країни була підсилена з боку державних та приватних суб'єктів.

На даний момент Шведський інститут налічуе близько 140 співробітників. Загальний бюджет Інституту становить 505 млн. шведських крон. Інститут співпрацюе 3 шведськими по- сольствами та консульствами по всьому світу, а також з Центрами шведських досліджень. Цей державний орган перебуває під керівництвом Міністерства Закордонних Справ Швеції. Даний Інститут розглядається МЗС Швеції не просто як координатор культурних обмінів, але як повноцінний суб'єкт громадської дипломатії, який використовуе культуру, цінності та інформацію про Швецію для підвищення конкурентоспроможності країни, охоплюючи усі сфери взаємодії.

Більш конкретними фрункціями Шведського Інституту є: адміністрування візитів до Швеції іноземних академічних груп, контроль за проведенням двосторонніх студентських обмінів та організація лекцій шведських професорів у закордонних університетах.

В цілому, статут Шведського інституту цілком допускае фрункціональний дуалізм, тобто організація працює як в культурній, так і в економічній copepax - для вирішення цього завдання Шведський інститут співпрацює 3 національними компаніями і агентством Team Sweden, яке відповідає за інформаційну складову у даній сорері.

Організаційна структура Шведського інституту складається з чотирьох підрозділів, розділених за галузевим принципом. Так, Департамент комунікацій і управління бізнесом займається комплексною фрункціональною підтримкою і координацією міждержавних відносин у сфрері бізнесу. Зокрема, даний підрозділ відповідає за зв'язки з урядом, антикризове управління, оцифррування інформаціï, архіви та реєстр, фрінансове управління, HR та внутрішне обслуговування. Також департамент сприяє розвитку спільних бізнес-проєктів.

Департамент з питань міжнародних відносин відповідає за розвиток міжнародної співпраці, 3 акцентом на глобальний розвиток, обмін досвідом між організаціями і фрахівцями. Також у його обов'язки входять надання фінансової підтримки, планування і реалізація освітніх програм, а також розповсюдження інформації про наукові здобутки Швеції.

Інший підрозділ шведської комунікації відповідає за безпосередне інформування про країну за кордоном, зокрема про шведський досвід. Це поінформування відбувається через цифрові канали, тематичні інформаційні платформи та відділення Шведського інституту в Парижі (1971 р.). Згадане відділення відповідає за присутність даного інституту в Парижі, де його задача полягає у підвищенні зацікавленості до Швеції, i культури, а також сприяти обміну між країнами у культурній та освітній сфрерах. Щорічно понад 100000 відвідувачів приймають участь в різних шведських культурних та освітніх проєктах через відділення Шведського інституту в Парижі. Це робить його одним з найбільш відвідуваних іноземних культурних інститутів у фрранцузькій столиці та єдиним культурним представництвом від Шведського інституту за кордоном [8].

До завдань Інституту також входять: підтримка проєктів з розвитку демократії в країнах-партнерах; встановлення відносин між шведськими організаціями та лідерами думок за кордоном; підвищення рівня академічної мобільності серед студентів, викладачів і дослідників; фінансування і підтримка викладання шведської мови за кордоном, а також програм, орієнтованих на ви- 
вчення Швеції; окремо - підтримка фрілії Шведського інституту за кордоном. Вагомою особливістю Шведського інституту є те, що організація сама уповноважена проводити аудит якості своєї роботи за трьома критеріями: «діяльність», «результат» i «ефективність». Так, перший критерій «діяльність» організації охоплюе програми і проєкти, що реалізовуються Інститутом в громадській сорері: проведення заходів, організащія обмінів та зовнішні комунікації. "Результат» діяльності організації включає в себе оцінку рівня знань про Швецію в світі, рівень лояльності до Швеції та кількісний показник налагоджених зв'язків. Під «ефективністю» розуміється рівень привабливості шведських цінностей, рівень ризику виникнення конфрлікту 3 іншими країнами та розвиток торгівлі. Така оцінка діяльності потрібна Шведському інституту для синхронізації діяльності та отримання результатів не тільки в короткочасній, але й у довготривалій перспективі [7].

В цілому діяльність Шведського Інституту полягає у: аналізі візії та сприйнятті іноземними цільовими аудиторіями Швеції за кордоном; експертній підтримці приватних та державних суб'єктів, зацікавлених у просуванні шведського іміджу і досвіду за кордоном; поширенні інформації про цінності та досвід Швеції у сорері інноващій, сталого розвитку, культури і соціальної політики; поглибленні співпраці в регіоні Балтійського моря, що розглядається як передумова розвитку Швеції і безпосередньо регіону у довгостроковій перспективі; підтримці проєктів, що сприяють розвитку демократії у країнах-партнерах; налагодженні відносин зі світовими лідерами; підвищенні мобільності студентів, дослідників та кваліфрікованих працівників; підтримці вивчення шведської мови за кордоном; управлінні відділенням Шведського інституту в Парижі.

Станом на сьогодні Шведський інститут здійснюе ряд проєктів. В першу чергу, це стосується програм академічної мобільності, на яких організація робить особливий наголос. Цільовими регіонами виступають країни Східної Свропи, Південної Афррики, Близького Сходу та Азії (переважно - Китай). Програми академічного обміну е основним інструментом в рамках громадської культурної дипломатії, який безпосередньо впливає і до певної міри формуе "клуб друзів» 3 іноземною цільовою аудиторією. Однак, варто зазначити, що ефект від застосування даного методу досягається лише в довгостроковій перспективі. 3 метою підвищення експорту та зміцнення відносин з країнами Балтійського регіону, Шведський інститут реалізуе програми фрінансування для підприемців і міжнародних культурних медіа-проектів. У 2016 році організація розширила свої повноваження і отримала мандат на діяльність в рамках державних стратегій експорту, міграції, фремінізації зовнішньої політики та політики глобального розвитку [6].

Окрім завдання, поширювати інформацію про державу в різних регіонах світу, Шведський інститут надає перевагу взаємовигідним відносинам 3 державами Балтійського регіону. Це пояснюеться прагненням Швеції посилити інтеграцію країни всередині регіону перш за все 3 політичної точки зору, так як спільне бачення розвитку співпраці в межах Балтійського регіону має біль- шу питому вагу на платформах існуючих міжнародних організащій (Свропейський Союз, ООН).

32018 року на базі Шведського інституту діють дев'ять програм академічної мобільності, що дозволяють отримати ступінь магістра або доктора з різних галузей знань. Окремі стипендіальні проєкти розроблені для студентів країн Східної Європи, Африки та Туреччини. Найбільш відома програма академічної мобільності - «Visby Program» (1995 р.), яка дає можливість студентам 3 країн Балтії, Польщі та колишнього СРСР навчатися на програмах освітнього рівня магістр у вищих навчальних закладах Швеції, при цьому всі витрати на навчання і перебування покриваються Шведським інститутом.

З 2015 року Шведський інститут увійшов до складу об'єднання «Team Sweden», що ознаменувало появу нового профільного напрямку діяльності агентства - просування шведських підприемств на світовому ринку. Головне завдання об'єднання полягає в тому, щоб полегшити вихід на експортний ринок защікавлених шведських підприємщів. У зв'язку з цим «Теат Sweden» є майданчиком для обміну досвідом, спільного формулювання економічних завдань та вироблення механізмів їхньої реалізації, а також для створення діалогу між господарюючими суб'єктами як всередині, так і за межами країни.

Висновки. Висвітлено передумови та процес становлення Шведського інститу, що бере свій початок з 1945 року. Досліджено, що впродовж сімдесяти шести років даний Інститут спромігся сорормувати дієві інструменти та механізми $з$ міжнародної співпраці та став одним 3 центральних органів у системі громадської дипломатії країни. Проаналізувавши структуру Шведського інституту, особливо слід звернути увагу на те, що з самого початку своєї діяльності організація могла здійснювати широке коло повноважень в різних сферах з метою забезпечення ефрективності національної громадської дипломатії найбільш широким арсеналом засобів. 3 розвитком діяльності Шведського інституту, коло цих повноважень розширювалося: якщо на початковому етапі організація займалася лише адмініструванням державних культурних проєктів за кордоном і видавництвом спеціалізованої літератури про шведське суспільство, то в більш пізній час Інститут став здійснювати власні академічні, культурні і економічні проєкти із зарубіжними державами. З'ясовано, що до основних функцій Інституту належать: напрацювання стратегії розвитку іміджевої політики та громадської дипломатії країни в цілому, координація академічною мобільністю, поширення інформації про Швецію, налагодження співпраці у сфрері культури та бізнесу, вивчення шведської мови, управління відділенням Шведського інституту в Парижі. Встановлено, що діяльність Шведського інституту має надзвичайно широке охоплення, зокрема усі проєкти можна згрупувати за кількома основними напрямками: експертна підтримка приватних та державних суб'єктів, зацікавлених у просуванні шведського іміджу і досвіду за кордоном; проєкти з академічної мобільності, суспільно-просвітницькі заходи, профресійний обмін, фрінансування приватних культурних i комерційних проєктів, пов'язаних зі Швецією 
за кордоном. До дієвих інструментів з громадської дипломатії Шведського інституту слід віднести інформаційне наповнення у соціальних мережах (Facebook, Twitter та Instagram); запуск інформаційних порталів таких як: Sweden. se, Sharing Sweden, Image Bank Sweden тощо. Важливо підкреслити фрункціональний дуалізм даної організації, що полягає у поєднанні співп- раці як в культурній, так і в економічній сcрерах. Адже з моменту заснування Шведського інституту було прийнято рішення, що представленням країни будуть займатися не лише чиновники, діячі культури, науки і мистецтва, а й підприемці. У профрільних організаціях інших країн така комбінація не застосовується, що істотно вирізняє Інститут с поміж інших у світі.

\section{Список літератури:}

1. Белінська Т., Вовчук Л. Еволюція публічної дипломатії та іміджу Швеції (40-90-і pp. ХХ ст.). Acta de Historia \& Politica: Saeculum XXI. 2020. № 1. C. 24-31.

2. Боголюбова Н.М., Николаева Ю.В. Зарубежные культурные центры как самостоятельный актор внешней культурной политики. Вестник Санкт-Петербурского университета. 2008. Серия 6. Выпуск 2. С. 87-92.

3. Зольнова М.Г. Общественная дипломатия Швеции. Тренды и управление. 2014. № 2. С. 137-146.

4. Лушникова Л.А. Публичная дипломатия Швеции в период с 1945 по 2017 гг.: тенденции, фракторы, перспективы. Санкт-Петербург : СПбГУ, 2018. URL: https://dspace.spbu.ru/handle/11701/13835 (дата звернення: 15.07.2021).

5. Clerc, L., Glover, N. \& Jordan, P. Histories of Public Diplomacy and Nation Branding in the Nordic and Baltic Countries (Representing the Periphery). Brill-Nijhoff, 2015. 338 p.

6. Glover N. International Relations: Public diplomacy, national identity and the Swedish Institute $1945-1970$. Nordic Academic Press, 2011. P. 20.

7. Strategi för arbetet med Sverigebilden i utlandet - en vägledning. Sverige. April, 2017. URL: https://sharingsweden.se/ app/uploads/2017/04/Strategi-2.0-f\%C3\%B6r-arbetet-med-Sverigebilden-i-utlandet.pdf (дата звернення: 16.07.2021).

8. About SI. Svenska institutet. URL: https://si.se/ (дата звернення: 15.07.2021).

\section{References:}

1. Belinska T., Vovchuk L. (2020) Evolyuciya publichnoyi dy`plomatiyi ta imidzhu Shveciyi (40-90-i rr. XX st.) [The evolution of public diplomacy and the image of Swedenm (40-90s of the twentieth century)]. Acta de Historia \& Politica: Saeculum XXI, no. 1, pp. 24-31.

2. Bogolyubova N.M., Nikolaeva Yu.V. (2008) Zarubezhnye kul'turnye centry kak samostoyatel'nyj aktor vneshnej kul'turnoj politiki [Foreign cultural centres as independent actors in foreign cultural policy]. Vestnik SanktPeterburskogo universiteta, vol. 6, no. 2, pp. 87-92.

3. Zol'nova M.G. (2014) Obshchestvennaya diplomatiya Shvecii [Public diplomacy of Sweden]. Trendy $i$ upravlenie, no. 2, pp. 137-146.

4. Lushnikova L.A. (2018) Publichnaia diplomatiia Shvetsii v period s 1945 po 2017 gg.: tendentsii, factory, perspektivy [Public diplomacy of Sweden in the period from 1945 to 2017: trends, factors, prospects]. SanktPeterburg: SPbGU. Available at: https://dspace.spbu.ru/handle/11701/13835 (accessed 15 July 2021).

5. Clerc, L., Glover, N. \& Jordan, P. (2015) Histories of Public Diplomacy and Nation Branding in the Nordic and Baltic Countries (Representing the Periphery). Brill-Nijhoff, 338 p.

6. Glover N. (2011) International Relations: Public diplomacy, national identity and the Swedish Institute 1945-1970. Nordic Academic Press, p. 20.

7. Strategi för arbetet med Sverigebilden i utlandet - en vägledning. Sverige. April, 2017. Available at: https://sharingsweden.se/app/uploads/2017/04/Strategi-2.0-f\%C3\%B6r-arbetet-med-Sverigebilden-i-utlandet.pdf (accessed 16 July 2021).

8. About SI. Svenska institutet. Available at: https://si.se/ (accessed 15 July 2021). 